Article

\title{
Amaranth Meal and Environmental Carnobacterium maltaromaticum Probiotic Bacteria as Novel Stabilizers of the Microbiological Quality of Compound Fish Feeds for Aquaculture
}

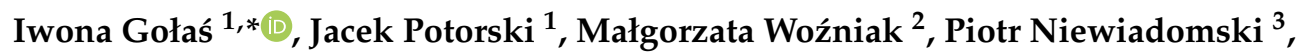 \\ Ma Guadelupe Aguilera-Arreola ${ }^{4}\left(\mathbb{D}\right.$, Araceli Contreras-Rodríguez ${ }^{5}$ and \\ Anna Gotkowska-Płachta ${ }^{1}$ \\ 1 Department of Water Protection Engineering and Environmental Microbiology, University of Warmia and \\ Mazury in Olsztyn, Prawocheńskiego 1, 10-720 Olsztyn, Poland; jacek.potorski@uwm.edu.pl (J.P.); \\ aniagp@uwm.eud.pl (A.G.-P.) \\ 2 Department of Tourism, Recreation and Ecology, University of Warmia and Mazury in Olsztyn, \\ Oczapowskiego 5, 10-957 Olsztyn, Poland; mawoz@uwm.edu.pl \\ 3 Department of Ichthyology and Aquaculture, University of Warmia and Mazury in Olsztyn Oczapowskiego \\ 5, 10-957 Olsztyn, Poland; piotr.niewiadomski@uwm.edu.pl \\ 4 Medical Bacteriology Laboratory, Department of Microbiology, Instituto Politécnico Nacional, Escuela \\ Nacional de Ciencias Biológicas, Mexico City, Mexico, Prolongación de Carpio y Plan de Ayala s/n, Col. \\ Santo Tomás, Del. Miguel Hidalgo, Mexico City D.F. CP. 11340, Mexico; lupita_aguilera@hotmail.com \\ 5 General Microbiology Laboratory, Department of Microbiology, Instituto Politécnico Nacional, Escuela \\ Nacional de Ciencias Biológicas, Mexico City, Mexico. Prolongación de Carpio y Plan de Ayala s/n, Col. \\ Santo Tomás, Del. Miguel Hidalgo, Mexico City D.F. CP. 11340, Mexico; aracelicontreras21@gmail.com \\ * Correspondence: iwonag@uwm.edu.pl; Tel.: +48-89-523-4557
}

Received: 24 June 2020; Accepted: 23 July 2020; Published: 25 July 2020

check for updates

\begin{abstract}
Fish feed should be characterized by microbiological stability to guarantee the optimal health of farmed fish. The aim of this study was to determine the efficacy of amaranth meal (Amaranthus cruentus) and a highly active environmental strain of probiotic bacteria, Carnobacterium maltaromaticum, as novel supplements that stabilize the quantitative and qualitative composition of microbiota in compound fish feeds for aquaculture, regardless of storage temperature. The total viable counts of mesophilic bacteria at $28^{\circ} \mathrm{C}\left(\mathrm{TVC} 28^{\circ} \mathrm{C}\right)$, hemolytic mesophilic bacteria $\left(\mathrm{Hem} 37^{\circ} \mathrm{C}\right)$, Staphylococcus sp. bacteria, aerobic spore-forming bacteria (ASFB), sulfite-reducing anaerobic spore-forming Clostridium sp. bacteria, yeasts, and molds were analyzed in control feed (CF), in feed supplemented with amaranth meal (AF), and in feed supplemented with amaranth meal and C. maltaromaticum (ACF), stored at a temperature of $4{ }^{\circ} \mathrm{C}$ and $20^{\circ} \mathrm{C}$ for 98 days. Amaranthus cruentus and C. maltaromaticum significantly reduced bacterial counts in fish feeds, regardless of the temperature and duration of storage. The antibacterial and antifungal effects of the tested additives were statistically significant $(p$ $\leq 0.05$ ). The studied novel supplements contribute to the microbiological safety of compound fish feeds. The tested additives could be recognized as the key ingredients of organic, environmentally friendly fish feeds, which guarantee the high quality of fish intended for human consumption.
\end{abstract}

Keywords: aquaculture; compound feed; antimicrobial stabilizers; Amaranthus cruentus; Carnobacterium maltaromaticum 


\section{Introduction}

Feed is one of the main factors that influence fish welfare and the microbiological status of water in aquaculture and freshwater ecology [1]. The nutritional value and microbiological quality of feed determine fish weight gains, and the sanitary and epidemiological safety of aquatic organisms and the aquatic environment [2-6].

Synbiotics containing probiotics and prebiotics enhance the health benefits of feed. They promote the growth and metabolic activity of beneficial microorganisms in the host's gastrointestinal tract without compromising endogenous gut microbiota [7-9]. Probiotics are natural microbiome bacteria that deliver multidirectional beneficial effects for living organisms (humans and animals) at the local and systemic level $[2,10]$. The role of probiotic feed microbiota in the maintenance of gut homeostasis is increasingly recognized as a critical success factor in fish breeding [6,11-13].

The group of probiotic bacteria includes members of the genus Carnobacterium [14-17]. Carnobacterium maltaromaticum, which colonizes natural aquatic habitats, is one of the most metabolically active probiotic bacteria in the digestive tract of animals. This bacterial species easily adapts to changes in habitat conditions such as temperature, salinity, and $\mathrm{pH}$, and it delivers health benefits for the host organism [14,18-20] Carnobacterium maltaromaticum effectively inhibits the development of pathogenic bacteria and is regarded as a potent immune stimulator in fish [14,21-23].

The growth and activity of probiotic bacteria are influenced by environmental conditions that can be optimized with the use of prebiotics [24,25]. Prebiotics are non-digestible food ingredients that beneficially affect the host by selectively stimulating the growth and/or activity of bacteria colonizing the gastrointestinal tract [7].

Animal and plant meals are one of the main ingredients of fish feeds [26]. However, plant meals contain anti-nutritional factors, and their applicability in compound fish feeds is limited [27]. One of exceptions is amaranth meal, characterized by a low content of anti-nutritional factors, mainly saponins and phytic acid [28].

Amaranth meal contains lignins and various compounds with antioxidant, antibacterial, antiviral, and fungistatic properties [29-31]. Amaranth seeds are also abundant in other health-promoting substances, such as squalene and fiber [32,33]. In a study by Niewiadomski et al. [34], feed supplemented with $20 \%$ of amaranth meal promoted the growth of rainbow trout (Oncorhynchus myskiss) and improved the digestibility of dietary nutrients. A microbiological analysis in a pilot study conducted by Potorski and Niewiadomski [35] revealed that amaranth supplementation can prevent excessive growth and proliferation of Staphylococcus sp. bacteria, Clostridium sp. anaerobic spore-forming bacteria, yeasts, and molds in compound fish feeds. A similar beneficial influence of amaranth meal on selected probiotic strains was also observed by Vieira et al. [36] who demonstrated that amaranth meal stimulated the fermentation ability of ten probiotic strains (Lactobacillus spp. and Bifidobacterium spp.)

The microbiological composition of fish feeds significantly influences fish health and weight gains. This parameter is particularly important if feeds contain harmful microorganisms that compromise fish health, disrupt digestive metabolism, and compromise the reproduction and survival of farmed fish [4]. Feeds should be characterized by microbiological stability and high quality to guarantee the optimal health status and physiological condition of farmed fish. Nevertheless, not all undesirable microorganisms are eliminated during fish feed production. According to the literature [4,37], the standard extrusion process does not guarantee complete elimination of various microorganisms from fish feeds. Furthermore, the metabolic activity of heterotrophic bacteria that survive in ready-made feeds involves the oxidative degradation of lipids and proteins. As a result, the nutritional value of feeds can be modified by natural feed microbiota or by contamination with exogenous microorganisms. Inadequate storage temperature and prolonged storage can also promote the development and metabolic activity of various groups, genera, and species of heterotrophic microorganisms [38].

Our previous experiment [39], which investigated the effect of C. maltaromaticum on heterotrophic microbiota, revealed that probiotic bacteria were the main factor responsible for a decrease in the counts of all analyzed bacterial groups in commercial fish feed. The results of studies conducted by 
other authors [40-42] demonstrated that amaranth meal increased the survival and growth rates of probiotic bacteria and improved the microbial stability of foods. The combined use of environmental probiotic bacteria and amaranth meal as stabilizers of the microbiological quality of fish feeds remains insufficiently researched. These facts have prompted the authors to evaluate the effectiveness of a highly active environmental isolate of $C$. maltaromaticum and amaranth meal in stabilizing the microbiological quality of fish feed. The aim of this study was to determine the efficacy of amaranth meal (Amaranthus cruentus) and a highly active environmental strain of probiotic bacteria, C. maltaromaticum, as novel supplements that stabilize the quantitative and qualitative composition of microbiota in compound fish feeds for aquaculture, regardless of storage temperature.

\section{Materials and Methods}

\subsection{Isolation and Identification of C. Maltaromaticum Probiotic Bacteria}

A probiotic strain of $C$. maltaromaticum was isolated from water samples collected from the benthic zone of Lake Leginskie (at a depth of $34 \mathrm{~m}$ ) located in north-eastern Poland ( $\mathrm{N}=53^{\circ} 58^{\prime} 51^{\prime \prime} \mathrm{N}$ and $\mathrm{E}$ $\left.=21^{\circ} 8^{\prime} 4^{\prime \prime}\right)$. The strain had been isolated during a previous study conducted by the Department of Environmental Microbiology of the University of Warmia and Mazury in Olsztyn.

The isolate was identified to species level by matrix-assisted laser desorption/ionization time-of-flight mass spectrometry (MALDI-TOF VITEK ${ }^{\circledR}$ MS) at the Department of Microbiology, Escuela Nacional de Ciencias Biológicas, Instituto Politécnico Nacional, in Mexico City, Mexico. The identification was additionally verified by $16 \mathrm{~S}$ rDNA (recombinant DNA) sequencing with the BigDye Terminator v3.1 kit in the ABI 3730xl genetic analyzer (Applied Biosystems, Foster City, USA). In addition, $16 \mathrm{~S}$ rDNA genes were sequenced by PCR with the use of 27F (5'-AGAGTTTGATCATTGGCTCAG-3') and 1492R (5'-GGTACC-TTGTTACGACTT-3') primers according to the method described by Gillan et al. [43]. The BLAST program available on the website of the National Center of Biotechnology Information [44] was used to identify DNA sequences. The results of $16 \mathrm{~S}$ rDNA sequencing are presented in Table S1 (Supplementary Materials).

After the identification process, C. maltaromaticum was considered as a probiotic strain based on the hemolysis assay, and its acid and bile tolerance properties, according to the guidelines developed by a joint FAO/WHO working group [45]. The hemolytic activity of $C$. maltaromaticum was determined on tryptone soya agar (TSA; Oxoid, Basingstoke, UK) with 5\% addition of defibrinated sheep blood

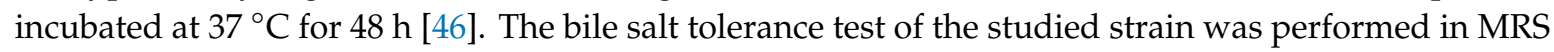
broth culture medium (Sigma - Aldrich, Germany) containing $0.5 \%, 1.0 \%$, or $2.0 \%$ bile salts (Oxoid LP0055) according to the procedure proposed by Succi et al. [47]. The C. maltaromaticum isolate was tested for acid tolerance based on its growth on medium with varying $\mathrm{pH}(1.5,2.5,3.5$, and 4.5), as described by Vijayarama et al. [48].

\subsection{Determination of the Metabolic Activity of Probiotic Bacteria Based on the Utilization of Different Carbon Sources}

The applicability of the environmental C. maltaromaticum isolate for further analysis was determined by analyzing the bacteria's metabolism based on its utilization of various carbon sources. The biochemical activity of the C. maltaromaticum probiotic isolate and its potential to compete for nutrients with feed microbiota were estimated using the OmniLog ${ }^{\circledR}$ System (Biolog, USA). A 96-well plate containing various carbon compounds was inoculated with the evaluated bacterial strain. The plate was incubated, and biochemical parameters were read in a microstation reader. The strain's utilization of different carbon compounds as sources of energy was determined based on the intensity of color reactions. 


\subsection{Compound Feed}

The experiment was performed on three types of extruded compound feeds: Control feed (CF) without the addition of amaranth meal, experimental feed containing $20 \%$ of amaranth meal (AF), and experimental feed containing $20 \%$ of amaranth meal and C. maltaromaticum probiotic bacteria (ACF). The composition of each feed is presented in Table 1. All feeds were formulated based on the recommendations of Hart et al. [49] and NRC [50]. The feeds were extruded with a co-rotating twin screw extruder (Metalchem, Poland) equipped with a $\varnothing 4.5 \mathrm{~mm}$ pellet stencil. The following extrusion processing parameters were applied: Screw speed-105-125 rpm, cutter speed-50 rpm, head temperature- $120^{\circ} \mathrm{C}$, barrel temperature of $130-150^{\circ} \mathrm{C}$ in $30 \mathrm{~s}$, die diameter-2.0 mm. Compound feeds were enhanced with a mixture of fish oil and soybean oil (5\% each). The tested strain of $C$. maltaromaticum was added to the oil mixture. Next, the probiotic oil suspension was added to two experimental feed samples. Tthe oil mixture was pumped into the feed at $0.9 \mathrm{Mpa}$ for $5 \mathrm{~min}$ with the use of a vacuum pump. The feed contained $40.0 \%$ crude protein, $15.0 \%$ crude fat, $3.0 \%$ crude ash, 37.0 nitrogen-free extract (NFE), and $5 \%$ water.

Table 1. Feeds composition ( $\mathrm{g} \cdot 100 \mathrm{~g}^{-1}$ dry diet).

\begin{tabular}{cccc}
\hline Ingredients & CF & Feed Type & \\
& 32.00 & $\mathbf{A F}^{\mathbf{2}}$ & ACF $^{\mathbf{3}}$ \\
\hline Soybean meal & 25.00 & 27.00 & 27.00 \\
Wheat flour & 0.00 & 10.00 & 10.00 \\
Amaranth meal & 15.00 & 20.00 & 20.00 \\
Fishmeal & 15.00 & 15.00 & 15.00 \\
Hydrolyzed feather meal & 5.00 & 15.00 & 15.00 \\
Codliver oil & 5.00 & 5.00 & 5.00 \\
Soybean oil & 1.00 & 5.00 & 5.00 \\
Vitamin premix & 1.00 & 1.00 \\
Mineral premix & 5 & 1.00 & 1.00 \\
C. maltaromaticum $\left(\mathrm{CFU} \cdot \mathrm{g}^{-1}\right)$ & 2.00 & 0.00 & $1.5 \times 10^{9}$ \\
\hline
\end{tabular}

1-control feed (CF); ${ }^{2}$-feed containing $20 \%$ amaranth (AF); ${ }^{3}$-feed containing $20 \%$ of amaranth and Carnobacterium maltaromaticum (ACF); ${ }^{4}$-Composition of the vitamin premix (IU. $1 \mathrm{~kg}^{-1}$ dry diet): Vitamin A-70,000 IU; vitamin D-200,000 IU; vitamin E-17,500 IU; vitamin K-867 IU; vitamin C-28,500 IU; vitamin B1-1067 IU; vitamin B2-2000 IU; vitamin B5-5334 IU; vitamin B6-1334 IU; vitamin B12-400 IU; biotin-200 IU; niacin—12,000 IU; folic acid-800 IU; inositol-20,000 IU; choline chloride-120,000 IU; betaine-75,000 IU; ${ }^{5}$-Composition of the mineral premix (g.1 kg-1 dry diet): $\mathrm{FeSO}_{4} \cdot \mathrm{H}_{2} \mathrm{O}-4334 \mathrm{~g} ; \mathrm{KI}-0.734 \mathrm{~g} ; \mathrm{CuSO}_{4} \cdot 5 \mathrm{H}_{2} \mathrm{O}-0.267 \mathrm{~g}$; $\mathrm{MnO}-0.734 \mathrm{~g}$; $\mathrm{ZnSO}_{4} \cdot \mathrm{H}_{2} \mathrm{O}-1250 \mathrm{~g} ; \mathrm{ZnO}-0.750 \mathrm{~g} ; \mathrm{Na}_{2} \mathrm{SeO}_{4}-0.034 \mathrm{~g} ; \mathrm{CFU} —$ colony forming unit.

\subsection{Experimental Design}

The prepared feeds $(\mathrm{CF}, \mathrm{AF}$, and $\mathrm{ACF})$ were used in an experiment that lasted for 98 days. The control feed (CF) was divided into two equal parts, and the feed containing $20 \%$ amaranth meal (AF) was divided into four equal parts under sterile conditions. Every $\mathrm{CF}$ and AF sample was placed in a separate, sterile, and tightly closed vessel made of dark glass. Two samples (CF $\left.4{ }^{\circ} \mathrm{C}, \mathrm{AF} 4{ }^{\circ} \mathrm{C}\right)$ were chill-stored at a temperature of $4{ }^{\circ} \mathrm{C}$, and two samples $\left(\mathrm{CF} 20^{\circ} \mathrm{C}, \mathrm{AF} 20^{\circ} \mathrm{C}\right.$ ) were stored at a temperature of $20^{\circ} \mathrm{C}$ throughout the experiment. Cultures of the environmental C. maltaromaticum strain were added to the remaining two samples (AF) at $1.5 \times 10^{9} \mathrm{CFU} \cdot \mathrm{g}^{-1}$ (Table 1 ). One of the samples containing probiotic bacteria $\left(\mathrm{ACF} 4{ }^{\circ} \mathrm{C}\right.$ ) was chill-stored at $4{ }^{\circ} \mathrm{C}$, and the other sample (ACF $20^{\circ} \mathrm{C}$ ) was stored at $20^{\circ} \mathrm{C}$ for 98 days.

\subsection{Microbiological Analyses}

All feed samples (CF, AF, and ACF) stored at $4{ }^{\circ} \mathrm{C}$ and $20^{\circ} \mathrm{C}$ were subjected to microbiological analyses after $7,14,21,28,35,42,4956,63,70,77,84,91$, and 98 days of the experiment. The following parameters were determined: Total counts of $C$. maltaromaticum bacteria on tryptone soya agar (TSA; Oxoid, Basingstoke, UK) with the addition of $3 \%$ yeast extract and $1.5 \%(w / v) \mathrm{NaCl}$ [14], total counts 
of mesophilic bacteria on tryptone soya agar (TSA; Oxoid, Basingstoke, UK) incubated at $28{ }^{\circ} \mathrm{C}$ for $48 \mathrm{~h}\left(\right.$ TVC $28^{\circ} \mathrm{C}$ ), total counts of hemolytic mesophilic bacteria on tryptone soya agar (TSA; Oxoid, Basingstoke, UK) with $5 \%$ addition of defibrinated sheep blood incubated at $37^{\circ} \mathrm{C}$ for $48 \mathrm{~h}$ (hemolytic mesophilic bacteria $(\mathrm{Hem}) 37^{\circ} \mathrm{C}$ ), total counts of aerobic spore-forming bacteria (ASFB) on an agar/broth medium (Biocorp, Warsaw, Poland) with glucose incubated at $28^{\circ} \mathrm{C}$ for $72 \mathrm{~h}$, counts of Staphylococcus sp. bacteria on the Chapman medium (Merck KgaA, Darmstadt, Germany) incubated at $37^{\circ} \mathrm{C}$ for $48 \mathrm{~h}$, counts of sulfite-reducing anaerobic spore-forming Clostridium sp. bacteria on the Wilson-Blair medium (Merck KgaA, Darmstadt, Germany) incubated at $37^{\circ} \mathrm{C}$ for $18 \mathrm{~h}$, and total yeast and mold counts on the Rose-Bengal-Chloramphenicol Agar (RGBC; Merck KgaA, Darmstadt, Germany) incubated at $28^{\circ} \mathrm{C}$ for 5 days.

All analyses were performed according to Polish Standard [51]. The potential pathogenicity of Hem $37^{\circ} \mathrm{C}$, Staphylococcus sp., and Clostridium sp. bacteria was determined based on their hemolytic activity on tryptone soya agar (TSA; Oxoid, Basingstoke, UK) with $5 \%$ addition of defibrinated sheep blood incubated at $37^{\circ} \mathrm{C}$ for $48 \mathrm{~h}$. Hemolysis was confirmed when a transparent zone was formed around the inoculated colonies [46]. Mean microbial counts were calculated based on the values determined in three replicates of the same sample of compound fish feed. Finally, the counts of all analyzed microorganisms were expressed in CFU $1 \mathrm{~g}^{-1}$ of compound feed.

\subsection{Statistical Analysis}

The mean values, standard deviations, standard errors, and confidence interval $(\mathrm{CI}=95 \%, \mathrm{~N}=3)$ of microbial counts in feeds $(\mathrm{CF}, \mathrm{AF}, \mathrm{ACF})$ stored at a temperature $4{ }^{\circ} \mathrm{C}$ and $20^{\circ} \mathrm{C}$ were calculated. The relationships between C. maltaromaticum bacterial counts and microbial (TVC $28^{\circ} \mathrm{C}$, Hem $37^{\circ} \mathrm{C}$, ASFB, Staphylococcus sp., Clostridium sp., yeasts, and molds) counts were determined by Spearman's non-parametric rank correlation test $(p \leq 0.05)$. The significance of differences in microbial counts between the analyzed types of fish feed (CF, AF, ACF) stored at different temperatures $\left(4\right.$ and $\left.20^{\circ} \mathrm{C}\right)$ and for different periods of time $(7,14,21,28,35,42,49,56,63,70,77,84,91$, and 98 days) was determined by one-way analysis of variance (ANOVA). Leven's test was used to assess the homogeneity of variance. The verified hypothesis was rejected when Leven's test produced statistically significant results. The Kruskal-Wallis test, a non-parametric version of the classical one-way ANOVA, was then applied. Statistical analyses were performed in the Statistica 13.3 software package (TIBCO Software Inc., Palo Alto, USA) [52].

\section{Results}

\subsection{Probiotic Properties of Carnobacterium Maltaromaticum}

The studied C. maltaromaticum isolate was not capable of causing hemolysis, which suggested that the strain was not pathogenic.

The strain tolerated the tested $\mathrm{pH}$ values. After $3 \mathrm{~h}$ acid exposure, the isolate's survival rate was higher at $\mathrm{pH} 2.5(76.1 \%)$ than at $\mathrm{pH} 1.5(65 \%)$, and it reached $82.3 \%$ at $\mathrm{pH} 3.5$ and $87.8 \%$ at $\mathrm{pH}$ 4.5. The bile salt tolerance test revealed a small difference in the survival rates of $C$. maltaromaticum. The highest isolate viability $(85.2 \%)$ was observed at a $2 \%$ concentration of bile salts, whereas the lowest viability $(79.5 \%)$ was noted at a $0.5 \%$ concentration of bile salts; $83.2 \%$ of $C$. maltaromaticum bacteria survived at a $1.0 \%$ concentration of bile salts (data not shown).

The C. maltaromaticum isolate tested in our study could be classified as a probiotic strain based on the results of the above analyses and according to the guidelines developed by a joint FAO/WHO working group [45].

\subsection{Metabolic Activity of C. maltaromaticum Probiotic Bacteria}

The results of the analyses examining the utilization of various carbon sources by the environmental C. maltaromaticum isolate are presented in Figure 1. The analyses performed in the Omnilog Gen III 
system (Biolog, Hayward, CA, USA) revealed that the evaluated strain actively metabolized 70 carbon sources. The studied C. maltaromaticum strain was capable of growth at $\mathrm{pH} 5$ and 6 , and in the presence of $1 \%, 4 \%$, and $8 \% \mathrm{NaCl}$. The tested isolate did not metabolize the following substrates: L-alanine, L-arginine, L-aspartic acid, L-glutamic acid, histidine, D-gluconic acid, and mucic acid. The analyzed strain did not metabolize vancomycin, tetrazolium blue chloride, L-pyroglutamic acid, $\alpha$-ketoglutaric acid, $\alpha$-ketobutyric acid, and acetoacetic acid. These results confirmed the very high biochemical activity of the studied environmental probiotic isolate, and suggested its potential to compete for nutrients with feed microbiota.

\begin{tabular}{|c|c|c|c|c|c|}
\hline $\begin{array}{c}\text { Negative } \\
\text { control }\end{array}$ & Positive control & D-Maltose & D-Trehalose & D-Cellobiose & Gentobiose \\
\hline Sucrose & D-Turanose & Stachyose & Dextrin & pH 6 & pH5 \\
\hline D-Raffinose & $\alpha$-D-Lactose & D-Melibiose & $1 \% \mathrm{NaCl}$ & $4 \% \mathrm{NaCl}$ & $8 \% \mathrm{NaCl}$ \\
\hline $\begin{array}{l}\text { N-Acetyl- } \beta \text {-D- } \\
\text { Mannosamine }\end{array}$ & $\begin{array}{c}\text { N-Acetyl- } \\
\text { D-Galactosamine }\end{array}$ & $\begin{array}{c}\text { N-Acetyl } \\
\text { Neuraminic acid }\end{array}$ & $\begin{array}{c}\text { Methyl- } \\
\text { D-Glucoside }\end{array}$ & D-Salicin & $\begin{array}{c}\text { N-Acetyl- } \\
\text { D-Glucosamine }\end{array}$ \\
\hline$\alpha$-D-Glucose & D-Mannose & D-Fructose & D-Galactose & 3-Methyl Glucose & D-Fucose \\
\hline L-Fucose & L-Rhamnose & Inosine & Sodium Lactate & Fusidic acid & D-Serine \\
\hline D-Sorbitol & D-Mannitol & Arabitol & myo-Inositol & Glycerol & D-Glucose-6PO 4 \\
\hline D-Fructose-6 $\mathrm{PO}_{4}$ & D-Aspartic acid & D-Serine & Troleandomycin & Rifamycin SV & Minocycline \\
\hline Gelatin & Glycyl-L-Proline & L-Alanine & L-Arginine & L-Aspartic acid & L-Glutamic acid \\
\hline Histidine & D-Glucuronic acid & L-Serine & Lincomycin & Guanidine $\mathrm{HCl}$ & Niaproof \\
\hline Pectin & Nalidixic acid & L-Galactonic acid & D-Gluconic acid & Methyl Pyruvate & Glucuronamide \\
\hline Mucic acid & Quinic acid & D- Saccharic acid & Vancomycin & Tween 40 & Tetrazolium Blue \\
\hline $\begin{array}{c}\text { p-Hydroxy- } \\
\text { Phenylacetic acid }\end{array}$ & L-Pyroglutamic acid & $\begin{array}{l}\text { D-Lactic Acid } \\
\text { Methyl Ester }\end{array}$ & L-Lactic acid & Lithium Chloride & $\alpha$-Ketoglutaric acid \\
\hline D-Malic acid & L-Malic acid & Bromosuccinic acid & $\begin{array}{l}\text { D-Galacturonic } \\
\text { acid }\end{array}$ & Citric acid & Potassium Tellurite \\
\hline Tetrazolium Violet & $\begin{array}{c}\mathrm{y} \text {-Aminobutryric } \\
\text { acid }\end{array}$ & $\begin{array}{c}\alpha-H y d r o x y b u t y r i c \\
\text { acid }\end{array}$ & $\begin{array}{c}\beta \text {-Hydroxy-D,L- } \\
\text { Butyric acid }\end{array}$ & $\begin{array}{c}\alpha-\text { Ketobutyric } \\
\text { acid }\end{array}$ & Acetoacetic acid \\
\hline Propionic acid & Acetic acid & Formic acid & Aztreonam & Sodium Butyrate & Sodium Bromate \\
\hline
\end{tabular}

Figure 1. The results of a metabolic activity test analyzing the chemical sensitivity of an environmental Carnobacterium maltaromaticum probiotic isolate and its ability to utilize different carbon sources (GEN III MicroPlate $\left.{ }^{\mathrm{TM}}\right)$. Purple color-metabolic activity of the C. maltaromaticum isolate, white color-no metabolic activity of the C. maltaromaticum isolate.

\subsection{The Quantitative and Qualitative Composition of Bacterial Microbiota in Compound Fish Feeds}

The mean (of three replicates) counts of mesophilic bacteria (TVC $28^{\circ} \mathrm{C}$ ), hemolytic mesophilic bacteria (Hem $37^{\circ} \mathrm{C}$ ), Staphylococcus sp., Clostridium sp., aerobic spore-forming bacteria (ASFB), yeasts and molds in $\mathrm{CF}, \mathrm{AF}$, and $\mathrm{ACF}$, and C. maltaromaticum bacteria stored at a temperature of $4{ }^{\circ} \mathrm{C}$ and 
$20{ }^{\circ} \mathrm{C}$ during the 98-day experiment are presented in Figure 2. The mean values, standard deviations, standard errors, and confidence interval of three replicates of microbial counts are shown in Table S2 (Supplementary Materials). In CF, microbial counts differed by several orders of magnitude, depending on the analyzed microbial group and the temperature and time of feed storage. In CF $4{ }^{\circ} \mathrm{C}$ samples, TVC $28^{\circ} \mathrm{C}$ and Clostridium sp. counts increased several-fold after 14 and 28 days of storage, respectively, relative to initial values. The counts of other microbial groups (Hem $37^{\circ} \mathrm{C}$, Staphylococcus sp., yeasts, and molds) in CF $4{ }^{\circ} \mathrm{C}$ samples continued to decrease in successive weeks of the experiment. The noted decrease ranged from $10^{1}$ to $10^{5} \mathrm{CFU}$ across the analyzed microbial groups, subject to storage time (Figure 2A).

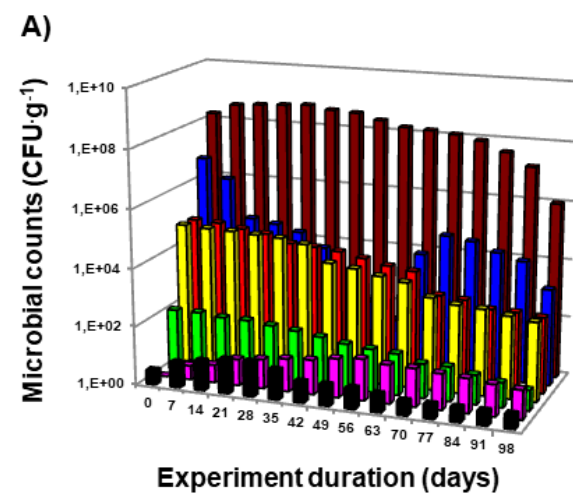

C)

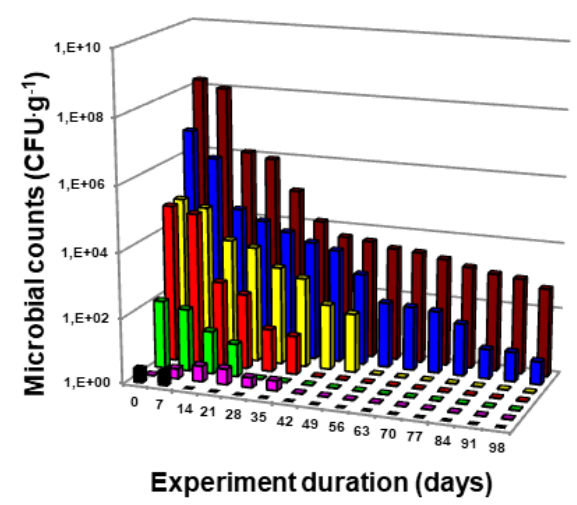

E)

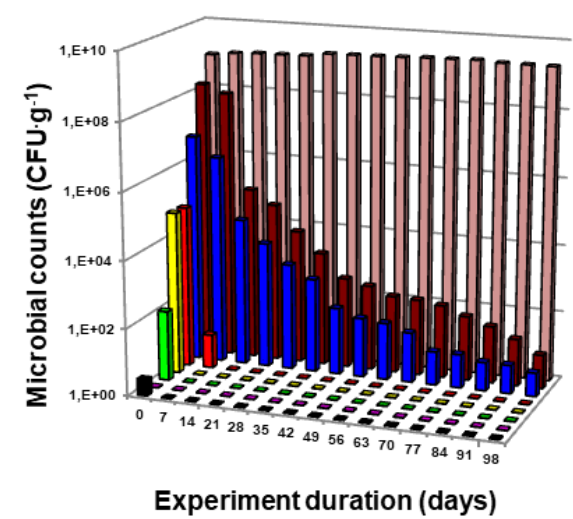

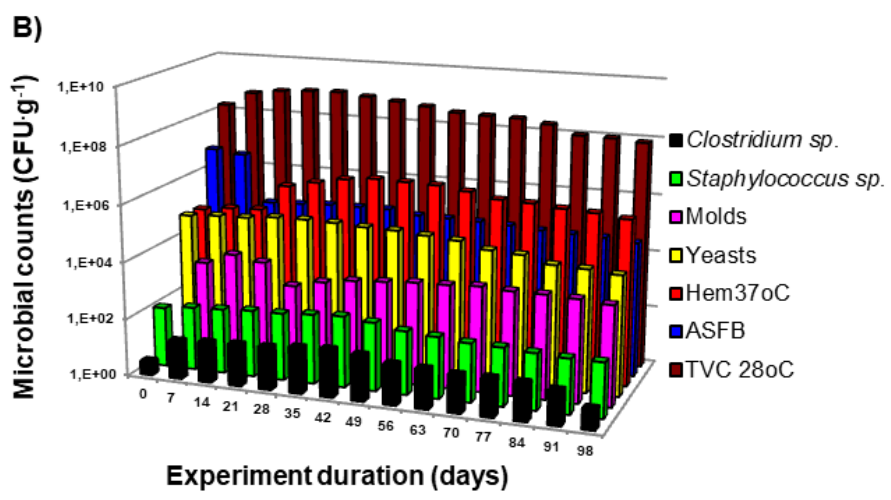

D)

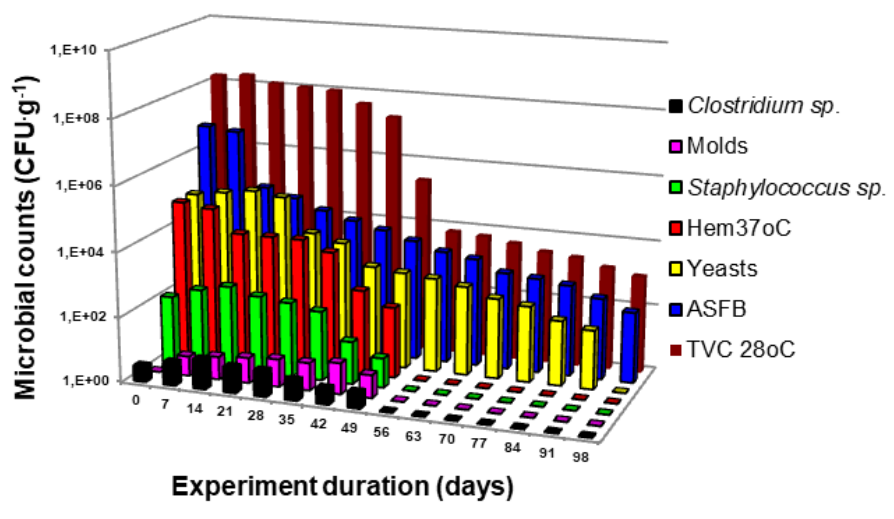

F)

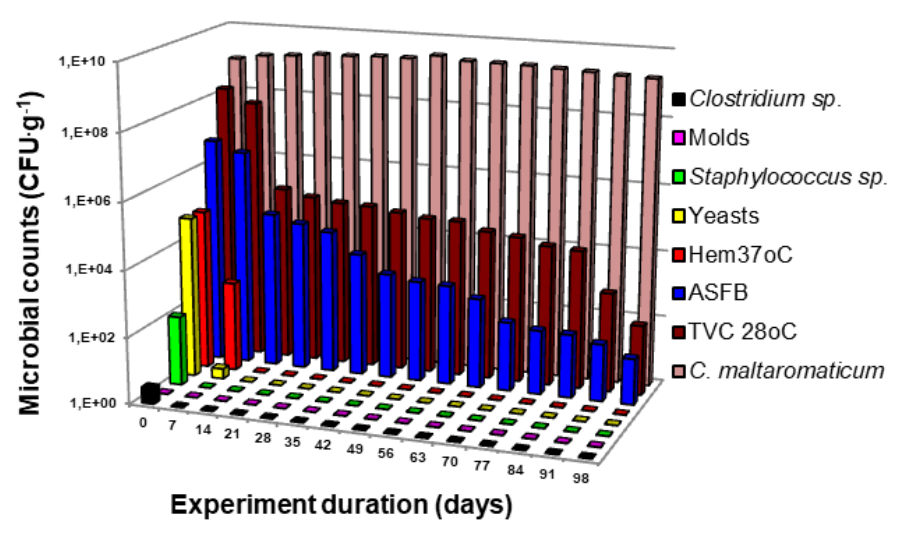

Figure 2. The mean (of three replicates) total viable counts (CFU.g ${ }^{-1}$ ) of mesophilic bacteria (TVC $28^{\circ} \mathrm{C}$ ), hemolytic mesophilic bacteria (Hem $37^{\circ} \mathrm{C}$ ), Staphylococcus sp., Clostridium sp., aerobic spore-forming bacteria (ASFB), yeasts, and molds in: (A) Control feed $\left(\mathrm{CF} 4{ }^{\circ} \mathrm{C}\right)$ stored at a temperature of $4{ }^{\circ} \mathrm{C},(\mathrm{B})$ control feed (CF $20^{\circ} \mathrm{C}$ ) stored at a temperature of $20^{\circ} \mathrm{C},(\mathrm{C})$ feed supplemented with $20 \%$ amaranth 
meal (AF $4{ }^{\circ} \mathrm{C}$ ) stored at a temperature of $4{ }^{\circ} \mathrm{C}$, (D) feed supplemented with $20 \%$ amaranth meal (AF $20^{\circ} \mathrm{C}$ ) stored at a temperature of $20^{\circ} \mathrm{C}$, (E) feed supplemented with $20 \%$ amaranth meal and Carnobacterium maltaromaticum bacteria (ACF $4{ }^{\circ} \mathrm{C}$ ) stored at a temperature of $4{ }^{\circ} \mathrm{C}$, and (F) feed supplemented with $20 \%$ amaranth meal and Carnobacterium maltaromaticum bacteria (ACF $20{ }^{\circ} \mathrm{C}$ ) stored at a temperature of $20^{\circ} \mathrm{C}$ during a 98 day experiment. The mean values, standard deviations, standard errors, and confidence interval of three replicates of microbial counts are shown in Table S2 (Supplementary Materials).

The counts of nearly all microorganisms (excluding ASBF) increased by around $100 \%$ in $\mathrm{CF} 20^{\circ} \mathrm{C}$ samples after 14,28 , and 42 days. In CF $20^{\circ} \mathrm{C}$ samples, TVC $28^{\circ} \mathrm{C}$ and yeast counts peaked on day 28 at $92 \times 10^{7}$ and $12 \times 10^{4} \mathrm{CFU} \cdot \mathrm{g}^{-1}$, respectively. The highest counts of potentially pathogenic bacteria (Hem $37^{\circ} \mathrm{C}$, Staphylococcus sp., Clostridium sp.) were noted after 42 days of feed storage. The maximum counts of Hem $37^{\circ} \mathrm{C}$, Staphylococcus sp., Clostridium sp., and molds were determined at $2.8 \times 10^{6}, 3.0$ $\times 10^{2}, 45$, and $2.5 \times 10^{3} \mathrm{CFU} \cdot \mathrm{g}^{-1}$, respectively. A minor decrease in microbial counts was noted in successive weeks of the experiment. However, on day 98, the counts of all evaluated microorganisms in CF $20^{\circ} \mathrm{C}$ samples were several-fold to several hundred-fold higher than those in $\mathrm{CF} 4{ }^{\circ} \mathrm{C}$ samples (Figure 2B).

In feed samples supplemented with $20 \%$ amaranth meal stored at a temperature of $4{ }^{\circ} \mathrm{C}(\mathrm{AF}$ $4^{\circ} \mathrm{C}$ ), the counts of all analyzed microbial groups decreased by several orders of magnitude after 14 days of the experiment. On day 28 , Hem $37^{\circ} \mathrm{C}\left(20 \mathrm{CFU} \cdot \mathrm{g}^{-1}\right)$ was the only potentially pathogenic microorganism in the studied samples. Toward the end of the experiment, $\mathrm{AF} 4{ }^{\circ} \mathrm{C}$ samples were colonized only by TVC $28^{\circ} \mathrm{C}\left(500 \mathrm{CFU} \cdot \mathrm{g}^{-1}\right)$ and ASFB $\left(5 \mathrm{CFU} \cdot \mathrm{g}^{-1}\right)$ (Figure 2C).

In $\mathrm{AF} 20^{\circ} \mathrm{C}$ samples, the decrease in the counts of potentially pathogenic $\mathrm{Hem} 37^{\circ} \mathrm{C}$ bacteria was considerably lower than that in $\mathrm{AF} 4^{\circ} \mathrm{C}$ samples. On day 28 , Hem $37^{\circ} \mathrm{C}$ counts in $\mathrm{AF} 20^{\circ} \mathrm{C}$ samples were determined at $1.0 \times 10^{4} \mathrm{CFU} \cdot \mathrm{g}^{-1}$, and they were 500 -fold higher than those in $\mathrm{AF} 4{ }^{\circ} \mathrm{C}$ samples on the same day. The counts of TVC $28^{\circ} \mathrm{C}, \mathrm{ASBF}$, and yeasts were also several-fold to several dozen-fold higher in AF $20^{\circ} \mathrm{C}$ samples than in AF $4{ }^{\circ} \mathrm{C}$ samples on the same days (Figure 2D). Hem $37^{\circ} \mathrm{C}$, Staphylococcus sp., and Clostridium sp. survived for longer periods of time in AF $20^{\circ} \mathrm{C}$ than in AF $4{ }^{\circ} \mathrm{C}$. Hem $37^{\circ} \mathrm{C}$, Staphylococcus sp., and Clostridium sp. were eliminated from AF $20^{\circ} \mathrm{C}$ samples only after 56 days, and from $\mathrm{AF} 4^{\circ} \mathrm{C}$-already after 14 or 28 days of the experiment (Figure 2C,D).

Feed samples supplemented with $20 \%$ amaranth meal and a highly active environmental strain of C. maltaromaticum probiotic bacteria (ACF $4{ }^{\circ} \mathrm{C}, \mathrm{ACF} 20^{\circ} \mathrm{C}$ ) were characterized by the lowest counts (Figure 2E,F) and the lowest survival rate of all analyzed microbial groups, regardless of storage temperature (Table S3). Potentially pathogenic Staphylococcus sp., Clostridium sp., and Hem $37^{\circ} \mathrm{C}$ bacteria were not detected in ACF $4{ }^{\circ} \mathrm{C}$ and ACF $20^{\circ} \mathrm{C}$ samples already after 7 days. In the first two weeks of the experiment, TVC $28^{\circ} \mathrm{C}$ counts decreased around 1000 fold, ASFB counts decreased more than 100-fold, and yeast counts decreased several fold in ACF $4{ }^{\circ} \mathrm{C}$ and ACF $20^{\circ} \mathrm{C}$ samples relative to the initial values. On day $98, \mathrm{ACF} 4{ }^{\circ} \mathrm{C}$ samples were colonized only by TVC $28^{\circ} \mathrm{C}$ and ASBF at 10 and $5 \mathrm{CFU} \cdot \mathrm{g}^{-1}$, respectively (Figure 2E). TVC $28^{\circ} \mathrm{C}$ and ASFB counts were higher in ACF $20^{\circ} \mathrm{C}$ at 120 and $20 \mathrm{CFU} \cdot \mathrm{g}^{-1}$, respectively (Figure $2 \mathrm{~F}$ ). Additionally, Spearman's test revealed significant $(p \leq 0.05)$ negative correlations between $C$. maltaromaticum counts and almost all microbial populations (except for Clostridium sp. and molds) in ACF, regardless of storage temperature (Table 2).

The differences in the quantitative and qualitative composition of bacterial and fungal microbiota in the analyzed types of fish feeds (CF, AF, and ACF) stored at different temperatures $\left(4{ }^{\circ} \mathrm{C}\right.$ and $\left.20^{\circ} \mathrm{C}\right)$ and for different periods of time were confirmed by the statistical analysis (Table 3). The Kruskal-Wallis test revealed significant $(p \leq 0.05)$ differences in the counts of all analyzed microorganisms between the evaluated feeds (CF, AF, and ACF) and in ASFB and yeast counts in feed samples stored for different periods of time. Significant $(p \leq 0.05)$ differences were also observed in Staphylococcus sp., Clostridium sp., and mold counts in feed samples stored at different temperatures, and in $\mathrm{TVC} 28^{\circ} \mathrm{C}, \mathrm{Hem} 37^{\circ} \mathrm{C}$, Staphylococcus sp., and Clostridium sp. counts in feed samples stored for different periods of time. 
Table 2. The values of correlation coefficients between microbial counts in feed supplemented with $20 \%$ amaranth meal and C. maltaromaticum probiotic bacteria (ACF) stored at 4 and $20^{\circ} \mathrm{C}$. The correlations between microbial counts in ACF $4{ }^{\circ} \mathrm{C}(\mathrm{N}=14)$ and ACF $20^{\circ} \mathrm{C}(\mathrm{N}=14)$ samples were analyzed with Spearman's test.

\begin{tabular}{|c|c|c|c|c|c|c|c|c|c|c|}
\hline & \multicolumn{10}{|c|}{ Microorganisms } \\
\hline & \multicolumn{2}{|c|}{$\begin{array}{c}C . \\
\text { maltaromaticum }\end{array}$} & \multicolumn{2}{|c|}{$\operatorname{TVC} 28^{\circ} \mathrm{C}^{1}$} & \multicolumn{2}{|c|}{ Hem $37^{\circ} \mathrm{C}^{2}$} & \multicolumn{2}{|c|}{$\begin{array}{l}\text { Staphylococcus } \\
\text { sp. }\end{array}$} & \multicolumn{2}{|c|}{ Yeasts } \\
\hline & $4{ }^{\circ} \mathrm{C}$ & $20^{\circ} \mathrm{C}$ & $4^{\circ} \mathrm{C}$ & $20^{\circ} \mathrm{C}$ & $4^{\circ} \mathrm{C}$ & $20^{\circ} \mathrm{C}$ & $4^{\circ} \mathrm{C}$ & $20^{\circ} \mathrm{C}$ & $4^{\circ} \mathrm{C}$ & $20^{\circ} \mathrm{C}$ \\
\hline $\operatorname{TVC} 28^{\circ} \mathrm{C}^{1}$ & -0.904 * & -0.535 * & & & & & & & & \\
\hline Hem $37^{\circ} \mathrm{C}^{2}$ & -0.763 * & $-0.713^{*}$ & 0.723 * & $0.763 *$ & & & & & & \\
\hline Staphylococcus sp. & $-0.677^{*}$ & -0.580 * & 0.511 & 0.577 & $0.715^{*}$ & $0.755^{*}$ & & & & \\
\hline Yeasts & -0.763 * & -0.578 * & 0.763 * & 0.975 * & 0.997 & $0.782 *$ & $0.755^{*}$ & 0.591 & & \\
\hline ASFB $^{3}$ & $-0.894 *$ & $-0.535 *$ & 0.957 & 0.999 & $0.723 *$ & 0.763 * & 0.577 & 0.577 & $0.763 *$ & 0.975 * \\
\hline
\end{tabular}

${ }^{1}$-mesophilic bacteria (TVC $\left.28{ }^{\circ} \mathrm{C}\right) ;{ }^{2}$-hemolytic mesophilic bacteria (Hem $37{ }^{\circ} \mathrm{C}$ ); ${ }^{3}$-aerobic spore-forming bacteria (ASFB); *- statistically significant correlations in Spearman's test $(p \leq 0.05)$.

Table 3. The quantitative composition of microorganisms in control feed (CF), feed supplemented with $20 \%$ amaranth meal (AF), and feed supplemented with $20 \%$ amaranth meal and Carnobacterium maltaromaticum bacteria (ACF) stored at different temperatures (4 and $\left.20{ }^{\circ} \mathrm{C}\right)$ for $7,14,21,28,35,42,49$, $56,63,70,77,84,91$, and 98 days, validated in the Kruskal-Wallis test $(\mathrm{N}=84)$.

\begin{tabular}{cccc}
\hline \multirow{2}{*}{ Microorganisms } & \multicolumn{3}{c}{ Differences $(p)$ between } \\
\cline { 2 - 4 } & Feed Type & Storage Temperature & Storage Time \\
\hline TVC $28^{\circ} \mathrm{C}^{1}$ & $0.0000^{*}$ & 0.2194 & $0.0242^{*}$ \\
Hem $37^{\circ} \mathrm{C}^{2}$ & $0.0000^{*}$ & 0.3058 & $0.0476^{*}$ \\
Staphylococcus sp. & $0.0000^{*}$ & $0.0456^{*}$ & $0.0493^{*}$ \\
Yeasts & $0.0050^{*}$ & 0.0550 & $0.0011^{*}$ \\
ASFB & $0.0005^{*}$ & 0.2785 & $0.0005^{*}$ \\
Clostridium sp. & $0.0001^{*}$ & $0.0238^{*}$ & $0.0483^{*}$ \\
Molds & $0.0003^{*}$ & $0.0048^{*}$ & 0.9979 \\
\hline
\end{tabular}

${ }_{1}^{1}$-mesophilic bacteria (TVC $\left.28{ }^{\circ} \mathrm{C}\right) ;{ }^{2}$-hemolytic mesophilic bacteria (Hem $\left.37^{\circ} \mathrm{C}\right) ;{ }^{3}$-aerobic spore-forming bacteria (ASFB); * - statistically significant differences; one-way ANOVA, $p \leq 0.05$.

\section{Discussion}

The analyses of the quantitative and qualitative composition of microbiota in fish feed samples revealed significant differences $(p \leq 0.05)$ across the examined types of feed $(\mathrm{CF}, \mathrm{AF}, \mathrm{ACF})$, feed storage temperatures, and feed storage times. Control feed $(\mathrm{CF})$ was characterized by the highest counts, highest survival rates, and longest survival times of all analyzed microbial groups, which indicates that feed ingredients promote the growth of both specific feed microorganisms and potentially pathogenic microorganisms $[37,53,54]$. Similar results were reported by Petreska [4] and Gołaś et al. [55] who analyzed the counts of heterotrophic mesophilic bacteria and selected potentially pathogenic bacteria, yeasts, and molds in commercial feeds administered to intensively reared Silurus glanis L.

In our study, the counts of all specific feed microbiota and potentially pathogenic microorganisms (Hem $37^{\circ} \mathrm{C}$, Staphylococcus sp., Clostridium sp.) in feed supplemented with $20 \%$ amaranth meal (AF $4{ }^{\circ} \mathrm{C}$, AF $20^{\circ} \mathrm{C}$ ) decreased by 1 to 4 orders of magnitude relative to those determined in $\mathrm{CF} 4{ }^{\circ} \mathrm{C}$ and $\mathrm{CF} 20^{\circ} \mathrm{C}$. The survival times of potentially pathogenic bacteria (Hem $37^{\circ} \mathrm{C}$, Staphylococcus sp., Clostridium sp.) were also significantly shorter in AF $4{ }^{\circ} \mathrm{C}$ and $\mathrm{AF} 20^{\circ} \mathrm{C}$ than in $\mathrm{CF} 4{ }^{\circ} \mathrm{C}$ and $\mathrm{CF}$ $20^{\circ} \mathrm{C}$. The obtained results and the presence of significant differences $(p \leq 0.05)$ in the counts of all analyzed microbial groups between CF and AF samples indicate that feed supplementation with $20 \%$ amaranth meal inhibits the growth of bacterial and fungal microbiota regardless of storage temperature or duration (Table 3). The antibacterial and antifungal properties of amaranth meal are also confirmed by the decrease in the counts of the remaining microbial groups (TVC $28^{\circ} \mathrm{C}, \mathrm{ASFB}$, yeasts, molds) in 
$\mathrm{AF} 4{ }^{\circ} \mathrm{C}$ and $\mathrm{AF} 20^{\circ} \mathrm{C}$ samples in successive weeks of the experiment. The above could be attributed to the fact that amaranth meal contains lignins whose antioxidant, antibacterial, antiviral, and fungistatic properties contribute to the maintaining of the adequate microbiological quality of feed [31,56-59]. The addition of amaranth meal stabilizes natural microbiota in animal feeds, enhances the nutritional value of feeds, and improves performance.

Research studies have confirmed the beneficial influence of amaranth-supplemented feeds on the health status and body weight gains of rats [60], intensively farmed pigs [61,62], chickens [63], calves, lambs, sheep, and ruminants [56]. Studies investigating the effect of amaranth-supplemented feeds on fish in different farming systems also demonstrated that amaranth meal stimulated the immune system of fish [64], their growth performance, and the enzymatic activity of their gut microbiota $[5,65]$. The results of the present study indicate that amaranth meal can be effectively used to improve the quality and microbiological safety of fish feeds.

The counts of all studied microorganisms (TVC $28^{\circ} \mathrm{C}$, Hem $37^{\circ} \mathrm{C}$, ASFB, Staphylococcus sp., Clostridium sp., yeasts, and molds) were lowest in ACF $4^{\circ}$ and ACF $20^{\circ}$ relative to AF and CF stored at the corresponding temperatures. The counts, percentage viability, and survival times of the evaluated microbial groups were considerably lower in ACF $4^{\circ}$ and ACF $20^{\circ}$ than in AF $4^{\circ}$ and $\mathrm{AF} 20^{\circ}$ (Figure 2C-F; Table S3), which indicates that amaranth meal and C. maltaromaticum probiotic bacteria exert antibacterial and antifungal effects on natural microbiota and potentially pathogenic microorganisms in compound feed. The synergistic effects of the tested feed additives could be attributed to the symbiotic relationship between amaranth meal and the evaluated probiotic bacteria, and their ability to inhibit the growth and development of various microbial groups and genera. An in vitro study $[57,66]$ revealed that amaranth is a source of bioactive compounds that suppress the proliferation of many microorganisms, including Staphylococcus aureus, Bacillus, Escherichia coli, Salmonella typhi, Pseudomonas aeruginosa, Proteus mirabillis, Klebsiella pneumoniae, and Candida albicans. Amaranth meal also promotes the development of many species of probiotic bacteria, such as Lactobacillus plantarum, L. paralimentarius, L. helveticus, L. sakei, Pediococcus pentosaceus, L. paralimentarius, Enterococcus mundtii, E. hermanniensis, E. durans, Enterococcus sp., and Leuconostoc mesenteroides, whose metabolic activity enhances the nutritional value and health benefits of food products [67-69]. An in vitro study conducted by Gullón et al. [70] demonstrated that amaranth was characterized by a high prebiotic potential and promoted the growth of probiotic microflora isolated from the human digestive tract. By inhibiting the growth and development of naturally occurring microorganisms and pathogenic microbiota in foodstuffs and feedstuffs $[5,66]$ probiotic bacteria and amaranth contribute to improving fish welfare and performance in various aquaculture systems [71-73].

The lowest counts of all evaluated microbial groups and genera and the shortest microbial survival times were noted in ACF samples regardless of storage temperature and storage time, which indicates that amaranth meal and C. maltaromaticum probiotic bacteria exert synergistic effects on the quantitative and qualitative composition of feed microbiota. Feed supplementation with $20 \%$ amaranth meal and C. maltaromaticum (ACF) bacteria completely inhibited the growth of most analyzed microorganisms (excluding ASFB and TVC $28{ }^{\circ} \mathrm{C}$ ) in feeds stored at $4{ }^{\circ} \mathrm{C}$ and $20{ }^{\circ} \mathrm{C}$ for 7 days. The results of our in vitro study were validated statistically, which suggests that the novel tested additives contribute to the microbiological stability of fish feeds regardless of storage conditions and storage time.

\section{Conclusions}

The results of the present study, which investigated the supplementation of compound fish feeds with innovative additives, amaranth meal, and a highly active environmental strain of probiotic bacteria, C. maltaromaticum, indicate that the tested additives exert synergistic effects and contribute to the microbiological stability of fish feeds regardless of the temperature and time of storage. The evaluated components decreased the counts, percentage viability, and survival times of various groups and genera of microorganisms that occur naturally in feeds, which suggests that they can minimize feed losses resulting from the growth and metabolic activity of autochthonous 
and allochthonous microbiota in feeds that are stored for excessive periods of time and/or at inadequate temperature. Excessive microbial growth lowers the nutritional value of feed, and decreases nutrient digestibility and assimilability, which may negatively affect fish performance in aquaculture. The addition of $20 \%$ amaranth meal and a highly active environmental strain of probiotic bacteria, C. maltaromaticum, to fish feed inhibited the growth of potentially pathogenic microbiota (Hem $37^{\circ}$, Staphylococcus sp., and Clostridium sp.) in vitro, which is important for the growth rate and welfare of fish. Due to their novel synergistic health-promoting properties, amaranth meal and environmental C. maltaromaticum bacteria could be recognized as the key ingredients of organic, environmentally friendly fish feeds, which guarantee the high quality of fish intended for human consumption.

Supplementary Materials: The following are available online at http://www.mdpi.com/2076-3417/10/15/5114/s1, Table S1: The identification of an environmental strain of Carnobacterium maltaromaticum bacteria based on $16 \mathrm{~S}$ rDNA sequence analysis. Table S2: The mean values $(X)$, confidence interval $(C I)(C I=95 \%, N=3)$, standard deviations (SD), and standard errors (SE) of microbial counts in control feed (CF), in feed supplemented with $20 \%$ amaranth meal (AF), and in feed supplemented with $20 \%$ amaranth meal and Carnobacterium maltaromaticum bacteria (ACF) stored at 4 and $20^{\circ} \mathrm{C}$ during 98 days of the experiment. Table S3: Survival rates of microorganisms (\%) in control feed (CF), feed supplemented with $20 \%$ amaranth meal (AF), and feed supplemented with $20 \%$ amaranth meal and Carnobacterium maltaromaticum bacteria (ACF) stored at 4 and $20{ }^{\circ} \mathrm{C}$ during 98 days of the experiment.

Author Contributions: Conceptualization, I.G. and M.W.; methodology, I.G., J.P., M.W., P.N., M.G.A.-A. and A.C.-R.; software, I.G.; validation, I.G., J.P., M.W. and P.N.; formal analysis, J.P. and P.N.; investigation, I.G., J.P., M.W. and P.N.; resources, I.G., M.W., M.G.A.-A. and A.C.-R.; data curation, I.G. and J.P.; writing-original draft preparation, I.G. and M.W.; writing-review and editing, M.W. and A.G.-P.; visualization, A.G.-P.; supervision, I.G. All authors have read and agreed to the published version of the manuscript.

Funding: This research received no external funding.

Acknowledgments: This study was supported by research grants No. 18.610-004-300 and No. 18.610.001-300 from the Ministry of Science and Higher Education (Poland). The project was financially co-supported by the Minister of Science and Higher Education under the program entitled "Regional Initiative of Excellence" for the years 2019-2022, Project No. 010/RID/2018/19, amount of funding PLN 12,000,000. The authors would like to thank Z. Filipkowska and E. Korzeniewska, Professors at the University of Warmia and Mazury in Olsztyn for the culturing and sequencing of $16 \mathrm{~S}$ rDNA of the tested C. maltaromaticum strain, and K. Glinska-Lewczuk (University of Warmia and Mazury in Olsztyn) for help in the statistical processing of data.

Conflicts of Interest: The authors declare that they have no conflict of interest. The funders had no role in the design of the study; in the collection, analyses, or interpretation of data; in the writing of the manuscript, or in the decision to publish the results.

\section{References}

1. Gołaś, I.; Szmyt, M.; Potorski, J.; Łopata, M.; Gotkowska-Płachta, A.; Glińska-Lewczuk, K. Distribution of Pseudomonas fluorescens and Aeromonas hydrophila bacteria in a recirculating aquaculture system during farming of uropean grayling (Thymallus thymallus L.) broodstock. Water 2019, 11, 376. [CrossRef]

2. Banu, M.R.; Akter, S.; Islam, M.R.; Mondol, M.N.; Hossain, M.A. Probiotic yeast enhanced growth performance and disease resistance in freshwater catfish gulsa tengra, Mystus cavasius. Aquac. Res. 2020, 16. [CrossRef]

3. Lauzon, H.L.; Dimitroglou, A.; Merrifield, D.L.; Ringo, E.; Davies, S.J. Probiotics and Prebiotics: Concepts, Definitions and History. In Aquaculture Nutrition: Gut Health, Probiotics and Prebiotics; Merrifield, D.L., Ringo, E., Eds.; Wiley Blackwell: Chichester, UK, 2014; pp. 169-184.

4. Petreska, M.; Ziberoski, J.; Zekiri, M. Fish feed microbiological status. JHED 2013, 4, 16-19.

5. Ramesh, S.; Chelladurai, G.; Haniffa, M.A. Isolation of enzyme producing bacteria from gut of Channa striatus fed on different herbs and probiotics diet. Int. J. Pharm. Pharm. Sci. 2013, 5, 195-198.

6. Robertson, P.A.W.; O’Dowd, C.; Burrells, C.; Williams, P.; Austin, B. Use of Carnobacterium sp. as a probiotic for Atlantic salmon (Salmo salar L.) and rainbow trout (Oncorhynchus mykiss, Walbaum). Aquaculture 2000, 185, 235-243. [CrossRef]

7. Gibson, G.R.; Roberfroid, M.B. Dietary modulation of the human colonic microbiota: Introducing the concept of prebiotics. J. Nutr. 1995, 125, 1401-1412. [CrossRef] 
8. Andersson, H.; Asp, N.-G.; Bruce, Å.; Roos, S.; Wadström, T.; Wold, A.E. Health effects of probiotics and prebiotics. A literature review on human studies. Scand. J. Food Nutr. 2001, 45, 58-75. [CrossRef]

9. Celi, P.; Verlhac, V.; Pérez, C.E.; Schmeisser, J.; Kluenter, A.-M. Biomarkers of gastrointestinal functionality in animal nutrition and health. Anim. Feed Sci. Technol. 2019, 250, 9-31. [CrossRef]

10. Alvarez-Olmos, M.I.; Oberhelman, R.A. Probiotic agents and infectious diseases: A modern perspective on a traditional therapy. Clin. Infect. Dis. 2001, 32, 1567-1576. [CrossRef]

11. Kim, D.H.; Austin, B. Cytokine expression in leucocytes and gut cells of rainbow trout, Oncorhynchus mykiss Walbaum, induced by probiotics. Vet. Immunol. Immunopathol. 2006, 114, 297-304. [CrossRef]

12. Merrifield, D.L.; Burnard, D.; Bradley, G.; Davies, S.J.; Baker, R.T.M. Microbial community diversity associated with the intestinal mucosa of farmed rainbow trout (Onchorhynchus mykiss). Aquac. Res. 2009, 40, 1064-1072. [CrossRef]

13. Wache, Y.; Auffray, F.; Gatesoupe, F.J.; Zambonino, J.; Gayet, V.; Labbe, L.; Quentelc, C. Cross effects of the strain of dietary Saccharomyces cerevisiae and rearing conditions on the onset of intestinal microbiota and digestive enzymes in rainbow trout, Onchorhynchus mykiss, fry. Aquaculture 2006, 258, 470-478. [CrossRef]

14. Kim, D.H.; Austin, B. Characterization of probiotic carnobacteria isolated from rainbow trout (Oncorhynchus mykiss) intestine. Lett. Appl. Microbiol. 2008, 47, 141-147. [CrossRef] [PubMed]

15. Servin, A.L.; Coconnier, M.H. Adhesion of probiotic strains to the intestinal mucosa and interaction with pathogens. Best Pract. Res. Clin. Gastroenterol. 2003, 17, 741-754. [CrossRef]

16. Timmerman, H.M.; Koning, C.J.M.; Mulder, L.; Rombouts, F.M.; Beynen, A.C. Monostrain, multistrain and multispecies probiotics. A comparison of functionality and efficacy. Int. J. Food Microbiol. 2004, 96, 219-233. [CrossRef]

17. Verschuere, L.; Rombaut, G.; Sorgeloos, P.; Verstraete, W. Probiotic bacteria as biological control agents in aquaculture. Microbiol. Mol. Biol. Rev. 2000, 64, 655-671. [CrossRef]

18. Alfaro, B.; Hernández, I.; Le Marc, Y.; Pin, C. Modelling the effect of the temperature and carbon dioxide on the growth of spoilage bacteria in packed fish products. Food Control 2013, 29, 429-437. [CrossRef]

19. Kim, D.; Kang, K.; Hae Kyung, C.; Jisoon, I.; Kwisung, P. Carnobacterium isolated from caviar of sturgeon (Acipenser ruthenus) farmed in Korea. J. Bacteriol. Virol. 2015, 45, 151-154. [CrossRef]

20. Leroi, F. Occurrence and role of lactic acid bacteria in seafood products. Food Microbiol. 2010, 27, 698-709. [CrossRef]

21. Haniffa, M.A.; Ramakrishnan, C.M.; Sheela, P.J. Effect of probiotics on survival and growth of Heteropneustes fossilis. Int. J. Pharma Res. Health Sci. 2015, 3, 784-793.

22. Ringø, E. The ability of carnobacteria isolated from fish intestine to inhibit growth of fish pathogenic bacteria: A screening study. Aquac. Res. 2008, 39, 171-180. [CrossRef]

23. Ringø, E.; Schillinger, U.; Holzapfel, W. Antibacterial abilities of lactic acid bacteria isolated from aquatic animals and the use of lactic acid bacteria in aquaculture. In Microbial Ecology in Growing Animals; Holzapfel, W., Naughton, P., Eds.; Elsevier: Edinburgh, UK; London, UK; New York, NY, USA; Oxford, UK; Philadelphia, PA, USA; St Louis, MO, USA; Sydney, Australia; Toronto, ON, Canada, 2005; pp. 418-453.

24. Gatesoupe, F.J. Probiotics and prebiotics for fish culture, at the parting of the ways. Aqua Feeds Formul. Beyond 2005, 2, 3-5.

25. Tripathi, M.K.; Giri, S.K. Probiotic functional foods: Survival of probiotics during processing and storage. Food Funct. 2014, 9, 225-241. [CrossRef]

26. Damusaru, J.H.; Moniruzzaman, M.; Parka, Y.; Seong, M.; Jung, J.-Y.; Kim, D.-J.; Bai, S.C. Evaluation of fish meal analogue as partial fish meal replacement in the diet of growing Japanese eel Anguilla japonica. Anim. Feed Sci. Technol. 2019, 247, 41-52. [CrossRef]

27. Krogdahl, Å.; Penn, M.; Thorsen, J.; Refstie, S.; Bakke, A.M. Important antinutrients in plant feedstuffs for aquaculture: An update on recent findings regarding responses in salmonids. Aquac. Res. 2010, 41, 333-344. [CrossRef]

28. Escudero, N.L.; de Arellano, M.L.; Luco, J.M.; Giménez, M.S.; Mucciarelli, S.I. Comparison of the chemical composition and nutritional value of Amaranthus cruentus flour and its protein concentrate. Plant Food Hum. Nutr. 2004, 59, 15-21. [CrossRef] [PubMed] 
29. Januszewska-Jóźwiak, K.; Synowiecki, J. Characteristics and suitability of amaranth components in food biotechnology. Biotechnologia 2008, 3, 89-102. (In Polish)

30. Ratusz, K.; Wirkowska, M. Characterization of seeds and lipids of amaranthus. Oilseed Crops 2006, 26, 243-250. (In Polish)

31. Smeds, A.I.; Eklund, P.C.; Sjoholm, R.E.; Willfor, S.M.; Nishibe, S.; Deyama, T.; Holmbom, B.R. Quantification of a broad spectrum of lignans in cereals, oilseeds, and nuts. J. Agric. Food Chem. 2007, 55, 1337-1346. [CrossRef]

32. Gamel, T.H.; Linssen, J.P.; Mesallam, A.S.; Damir, A.A.; Shekib, L.A. Seed treatments affect functional and antinutritional properties of amaranth flours. J. Sci. Food Agric. 2006, 86, 1095-1102. [CrossRef]

33. Venskutonis, P.R.; Kraujalis, P. Nutritional components of amaranth seed and vegetables: A Review on composition, properties, and uses. Compr. Rev. Food Sci. Food Saf. 2013, 12, 381-412. [CrossRef]

34. Niewiadomski, P.; Gomułka, P.; Poczyczyński, P.; Woźniak, M.; Szmyt, M. Dietary effect of supplementation with amaranth meal on growth performance and apparent digestibility of rainbow trout Oncorhynchus myskiss. Pol. J. Nat. Sci. 2016, 31, 459-469.

35. Potorski, J.; Niewiadomski, P. The effect of amaranth meal on the quantitative and qualitative composition of microbiota in compound feeds stored at different temperatures. In Proceedings of the Poster Session Presentation at the 9th Polish Hydromicrobiological Conference-Hydromicro 2017, Microorganisms-Achievements and Challenges, Conference Proceedings, Olsztyn, Poland, 17-19 September 2017 ; p. 52.

36. Vieira, A.D.S.; Bedani, R.; Albuquerque, M.A.C.; Biscola, V.; Saad, S.M.I. The impact of fruit and soybean by-products and amaranth on the growth of probiotic and starter microorganisms. Food Res. Int. 2017, 97, 356-363. [CrossRef] [PubMed]

37. Ubiebi, C.O. Isolation and identification of bacterial isolates from poultry and fish feeds sold in Abraka, Delta State, Nigeria. J. Ind. Technol. 2017, 2, 14-20.

38. Zmysłowska, I.; Lewandowska, D. The effect of storage temperature on microbiological quality of fish feeds. Pol. J. Environ. Stud. 2000, 9, 223-226.

39. Potorski, J.A.; Gołaś, I. The effect of Carnbacterium maltaromaticum probiotic bacteria on commercial fish feed heterothropic microbiota. Fisheries Communiques 2018, 4, 1-5. (In Polish)

40. Kocková, M.; Valík, L. Suitability of cereal porridges as substrate for probiotic strain Lactobacillus rhamnosus GG. Potravin. Slovak J. Food Sci. 2013, 7, 22-27. [CrossRef]

41. Liptáková, D.; Matejčeková, Z.; Valík, L. Lactic acid bacteria and fermentation of cereals and pseudocereals. In Fermentation Processes; Jozala, A.F., Ed.; Intech Publisher: London, UK; Rijeka, Croatia, 2017; pp. $223-254$. [CrossRef]

42. Matejčeková, Z.; Liptáková, D.; Valík, L. Fermentation of milk- and water-based amaranth mashes. Acta Chim. Slov. 2015, 8, 140-145. [CrossRef]

43. Gillan, D.C.; Speksnijder, A.; Zwart, G.; De Ridder, C. Genetic diversity of the biofilm covering Montacuta ferruginosa (Mollusca, Bivalvia) as evaluated by denaturing gradient gel electrophoresis analysis and cloning of PCR-amplified gene fragments coding for 16S rRN. Appl. Environ. Microbiol. 1998, 64, 3464-3472. [CrossRef]

44. NCBI. National Center for Biotechnology Information, U.S. National Library of Medicine. Available online: http://blast.ncbi.nlm.nih.gov/Blast.cgi (accessed on 10 April 2017).

45. Guidelines for the Evaluation of Probiotics in Food. Food and Agriculture Organization of the United Nations, World Health Organization. In Proceedings of the Report of a Joint FAO/WHO Working Group on Drafting Guidelines for the Evaluation of Probiotics in Food, London, ON, Canada, 30 April-1 May 2002.

46. Chang, C.I.; Liu, W.Y.; Shyu, C.Z. Use of prawn blood agar hemolysis to screen for bacteria pathogenic to cultured tiger prawns Penaeus monodon. Dis. Aquat. Organ. 2000, 43, 153-157. [CrossRef]

47. Succi, M.; Tremonte, P.; Reale, A.; Sorrentino, E.; Grazia, L.; Pacifico, S.; Coppola, R. Bile salt and acid tolerance of Lactobacillus rhamnosus strains isolated from Parmigiano Reggiano cheese. FEMS Microbiol. Lett. 2005, 244, 129-137. [CrossRef] [PubMed] 
48. Vijayaram, S.; Robinson, J.P.; Kannan, S. Synthesis of antibacterial and anticancer substances by Bacillus sp. PRV3 and Bacillus sp. PRV23, an intestinal probiotics of Indian fresh water fish. Int. J. Pharm. Sci. Rev. Res. 2017, 43, 208-219.

49. Hart, S.D.; Brown, B.J.; Gould, M.L.; Robar, M.L.; Witt, E.M.; Brown, P.B. Predicting the optimal dietary amino acid profile for growth of juvenile yellow perch with whole body amino acid concentrations. Aquac. Nutr. 2010, 16, 248-253. [CrossRef]

50. NRC. Nutrient Requirements of Fish and Shrimp. National Research Council (US). In Committee on the Nutrient Requirements of Fish and Shrimp; The National Academy Press: Washington, DC, USA, 2011.

51. Polish Standard PN-R-64791:1994. Animal Feeds. Microbiological Requirements and Analyses. Available online: http://www.statsoft.com/Products/STATISTICA/Product-Index (accessed on 6 January 2019).

52. Crump, J.A.; Griffin, P.M.; Angulo, F.J. Bacterial contamination of animal feed and its relationship to human foodborne illness. Clin. Infect. Dis. 2002, 35, 859-865. [CrossRef]

53. Zmysłowska, I.; Kolman, R.; Krause, J. Bacteriological evaluation of water, feed and sturgeon (Acipenser baeri Brandt) fry quality during intensive rearing in cooling water. Arch. Pol. Fish. 2003, 1, 91-98.

54. Gołaś, I.; Zmysłowska, I.; Harnisz, M.; Teodorowicz, M. The microbiological state of fish feed, water and Silurus glanis L. skin of fry during intensive rearing. Bull. Sea Fish. Inst. 2004, 1, 3-14.

55. Alegbejo, J.O. Nutritional value and utilization of amaranthus (Amaranthus sp.) —A review. BAJOPAS 2013, 6, 136-143. [CrossRef]

56. Amare, G.A.; Unakal, C.G. Effect of aqueous and ethanol extracts of Ocimum lamiifolium and Amaranthus dubius against bacteria isolated from clinical specimen. IJPIR 2013, 3, 10-14.

57. Peter, K.; Gandhi, P. Rediscovering the therapeutic potential of Amaranthus species: A review. EJBAS 2017, 4, 196-205. [CrossRef]

58. Smeds, A.I.; Willfor, S.M.; Pietarinen, S.P.; Peltonen-Sainio, P.; Reunanen, M.H.T. Occurrence of "mammalian" lignans in plant and water sources. Planta 2007, 226, 632-646. [CrossRef]

59. Kamela, S.L.A.; Mouokeu, R.S.; Rawson, A.; Maffo Tazoho, G.; Moh, L.G.; Etienne, P.T.; Jules-Roger, K. Influence of processing methods on proximate composition and dieting of two Amaranthus species from West Cameroon. J. Food Sci. 2016, 1-8. [CrossRef]

60. Olufemi, B.E.; Assiak, I.E.; Ayoade, G.O.; Onigemo, M.A. Studies on the effect of Amaranthus spinosus leaf extract on the hematology of growing pigs. Afr. J. Biomed. Res. 2003, 6, 149-150. [CrossRef]

61. Zraly, Z.; Pisarikova, B.; Hudcova, H.; Trckova, M.; Herzig, I. Effect of feeding amaranth on growth efficiency and health of market pigs. Acta Vet. Brno 2004, 73, 437-444. [CrossRef]

62. Ravindran, V.; Hood, R.L.; Gill, R.J.; Kneale, C.R.; Bryden, W.L. Nutritional evaluation of grain amaranth (Amaranthus hypochondriacus) in broiler diets. Anim. Feed Sci. Technol. 1996, 63, 323-331. [CrossRef]

63. Vaseeharan, B.; Thaya, R. Medicinal plant derivatives as immunostimulants: An alternative to chemotherapeutics and antibiotics in aquaculture. Aquac. Int. 2014, 22, 1079-1091. [CrossRef]

64. Virk, P.; Saxena, P.K. Potential of Amaranthus seeds in supplementary feed and its impact on growth in some carps. Bioresour. Technol. 2003, 86, 25-27. [CrossRef]

65. Maiyo, Z.C.; Ngure, R.M.; Matasyoh, J.C.; Chepkorir, R. Phytochemical constituents and antimicrobial activity of leaf extracts of three Amaranthus plant species. Afr. J. Biotechnol. 2010, 9, 3178-3182.

66. Carrizo, S.L.; Montes de Oca, C.E.; Hébert, M.E.; Saavedra, L.; Vignolo, G.; LeBlanc, J.G.; Rollán, G.C. Lactic acid bacteria from urope grain amaranth: A Source of vitamins and functional value enzymes. J. Mol. Microbiol. Biotechnol. 2017, 27, 289-298. [CrossRef]

67. Jekle, M.; Houben, A.; Mitzscherling, M.; Becker, T. Effects of selected lactic acid bacteria on the characteristics of amaranth sourdough. J. Sci. Food Agric. 2010, 90, 2326-2332. [CrossRef]

68. Sterr, Y.; Weiss, A.; Schmidt, H. Evaluation of lactic acid bacteria for sourdough fermentation of amaranth. Int. J. Food Microbiol. 2009, 136, 75-82. [CrossRef]

69. Gullón, B.; Gullón, P.; Tavaria, F.K.; Yáñez, R. Assessment of the prebiotic effect of quinoa and amaranth in the human intestinal ecosystem. Food Funct. 2016, 14, 3782-3788. [CrossRef] [PubMed]

70. Allameh, S.K.; Noaman, V.; Nahavandi, R. Effects of probiotic bacteria on fish performance. Adv. Tech. Clin. Microbiol. 2017, 1, 11.

71. Lara-Flores, M.; Olvera-Novoa, M.A.; Guzmán-Méndez, B.E.; López- Madrid, W. Use of the bacteria Streptococcus faecium and Lactobacillus acidophilus, and the yeast Saccharomyces cerevisiae as growth promoters in Nile tilapia (Oreochromis niloticus). Aquaculture 2003, 216, 193-201. [CrossRef] 
72. Mohapatra, S.; Chakraborty, T.; Prusty, A.K.; Das, P.; Paniprasad, K.; Mohanta, K.N. Use of different microbial probiotics in the diet of rohu, Labeo rohita fingerling: Effects on growth, nutrient digestibility and retention, digestive enzyme activities and intestinal microflora. Aquac. Nutr. 2012, 18,1-11. [CrossRef]

73. Ringø, E.; Løvmo, L.; Kristiansen, M.; Bakken, Y.; Salinas, I.R.; Myklebust, R.; Olsen, R.E.; Mayhew, T.M. Lactic acid bacteria vs. pathogens in the gastrointestinal tract of fish. Aquac. Res. 2010, 41, 451-467. [CrossRef]

(C) 2020 by the authors. Licensee MDPI, Basel, Switzerland. This article is an open access article distributed under the terms and conditions of the Creative Commons Attribution (CC BY) license (http://creativecommons.org/licenses/by/4.0/). 